\title{
A Study of Cultural-Loaded Words Translation in External Publicity Translation from Translator's Visibility
}

\author{
Wenjing Li, Hui Jia \\ East China University of Science and Technology, Shanghai, China \\ Email:1441349398@qq.com,jhflora@163.com
}

How to cite this paper: $\mathrm{Li}, \mathrm{W}$.J. and Jia, $\mathrm{H}$. (2020) A Study of Cultural-Loaded Words Translation in External Publicity Translation from Translator's Visibility. Open Access Library Journal, 7: e6495.

https://doi.org/10.4236/oalib.1106495

Received: June 2, 2020

Accepted: June 26, 2020

Published: June 29, 2020

Copyright $\odot 2020$ by author(s) and Open Access Library Inc.

This work is licensed under the Creative Commons Attribution International License (CC BY 4.0).

http://creativecommons.org/licenses/by/4.0/

(c) (i) Open Access

\begin{abstract}
Report on the Work of the Government (hereinafter "the work report" for short) is an important annual government document in China, which mainly includes the work summary of the previous year and the work prospect of the next year. This paper, with the help of Venuti's foreignization translation strategy, analyzes how cultural-loaded words are translated in the work report 2019 and tries to explore how translated Chinese culture can be accurately understood and accepted by Western audiences, and how Chinese culture can be better introduced to the world. The author believes that when translating external publicity texts, the translator should try to take foreignization as the main method and domestication as a complement, and convey the accurate meaning at the same time. Thus, the excellent Chinese culture can be introduced to the world, and the expression of the target language can be enriched. The translator should also bear the responsibility to promote the world culture to seek common ground while reserving differences, and enrich the cultural diversity.
\end{abstract}

\section{Subject Areas}

Linguistics

\section{Keywords}

External Publicity Translation, Foreignization, Translator's Visibility

\section{Introduction}

Report on the Work of the Government is a national report delivered by the premier of the State Council at the National People's Congress during the Two 
Sessions (National People's Congress (NPC) of the People's Republic of China and Chinese People's Political Consultative Conference (CPPCC)) each year. It is an important national political document which involves the general policies of the state of the Communist Party of China (CPC). "It has a strong theoretical, political and comprehensive nature, with distinctive characteristics of the times, practice and national characteristics" (Jia Yuling, 2011: 1) [1]. In addition, the work report belongs to the external publicity text. The purpose of the report is to let the target audience understand the work content of the Chinese government. If the target audience of the original text aims at the domestic reader, then, the English version aims at the English reader. External publicity translation is defined as "to translate a large amount of various information about China from Chinese into foreign languages, and publish, propagate it to foreign countries through books, periodicals, newspapers, radio, television, Internet and other media as well as international conferences" (Huang Youyi, 2004: 29) [2]. Most of the definitions of external publicity translation by different scholars focus on the following conditions: language translation, China-related information, through certain channels of communication. Compared with the above-mentioned definition of external publicity translation in a broad sense, in its narrow sense, the definition is quite specific: it includes "the translation of media reports, government document announcements, government and enterprise introduction, public signs and other stylistic translation" (Yu Yanying et al., 2016: 21) [3]. In external publicity translation, the China-related information or Chinese culture makes it hard to avoid the cultural translation, which is the key component in the translation of the work report. In the English version of the work report, the most obvious cultural translation is the translation of terminologies with Chinese characteristics and idioms. The former is the translation of modern Chinese culture, while the latter is the translation of traditional Chinese culture.

In the past 2 decades, external publicity translation has been one of the most important research topics of Chinese scholars. Different scholars have adopted different theories to guide the research of publicity translation, such as skopos theory (Tao Quanshen, 2005 [4]; Sun Xueying et al., 2014 [5]), functionalist translation theory (Xu Min et al., 2008 [6]; Xu Minhui et al., 2007 [7]), Hermeneutics theory (Hu Fangyi, 2014) [8] and so on. In the following parts, Venuti's translation strategy and translation of culture-loaded words, like political words, four-character expressions and allusions, in the work report will be discussed in detail.

\section{Translator's Invisibility}

Lawrence Venuti talked about the term invisibility in his book Translator's Invisibility-A History of Translation refers to the phenomenon that a translation does not like a translation. It "refers to ... an illusionistic effect of discourse, of the translator's own manipulation of the translating language, English in this case (Venuti, 2008: 1) [9]. He argues that: the more fluent the translation, the 
more invisible the translator, and, presumably, the more visible the writer or meaning of the foreign text... The illusion of transparency is an effect of a fluent translation strategy, of the translator's effort to ensure easy readability by adhering to current usage, maintaining continuous syntax, fixing a precise meaning (ibid). Venuti criticized this kind of complete domestication which belongs to the ethnocentrical violence. Under the regime of fluent translation, the translator works to make his or her work "invisible", producing the illusory effect of transparency that simultaneously masks its status as an illusion: the translated text seems "natural" that is, not translated (Venuti, 2008: 5) [9]. And the translations are rarely considered a form of literary scholarship (Venuti, 1998: 32) [10]. This will lead to a bad phenomenon: the translation is fluent, but the translator has to rewrite the original text more or less to ensure the fluency in the process of translation, and the identity of the translator also changes from the translator to another author of the text. By producing the illusion of transparency, a fluent translation masquerades as a true semantic equivalence when it in fact inscribes the foreign text with a partial interpretation, partial to English-language values, reducing if not simply excluding the very differences that translation is called on to convey (Venuti, 2008: 16) [9]. Thus, Venuti favors the foreignization in a policy of "resistance" to the dominant "ethnocentrically violent" values of publishers and literary reviewers (Jeremy, 2016: 246) [11]. Also, foreignization can highlight the heterogeneity of the source text. Schleiermacher argued two ways of translation: either the translator leaves the author in peace as much as possible and moves the reader towards him; or he leaves the reader in peace, as much as possible, and moves the author towards him (Lefevere 1977: 74) [12], which is quite similar to Venuti's translation theory: the former is foreignization while the latter is domestication.

At the end of the $20^{\text {th }}$ century, the cultural turn of translation became more and more obvious. The strategy of foreignization, which retained the cultural characteristics of the source language to a large extent, is an important part of the cultural translation. This paper attempts to analyze the cultural translation of the work report (2019) and explore the external publicity translation strategies.

\section{Literal and Free Translation Methods Used in Culture-Loaded Words}

External publicity texts do not belong to literary texts. Compared with literary texts, it has more obvious characteristics: much more formal styles, more terms with Chinese characteristics, and more distinct political nature. Therefore, it is not an easy job to translate publicity text well. Chinese scholar Huang Youyi (2004: 29) [2] put forward a "three closeness principle" of external publicity translation-namely, close to the reality of China's development, close to the foreign readers' demand for Chinese information and their thinking habits. In addition to "grasping political orientation, highlighting key information and conciseness of the original text", it is necessary to add the principle of "reap- 
pearance of aesthetic value" to the external publicity translation (Yu Yanying et al., 2016: 27) [3]. This is also in line with Yan Fu's translation strategy of "faithfulness, expressiveness and elegance", which adds aesthetic guidance to the translation practice. The features of external publicity texts directly affect the features of external publicity translation: seriousness, accuracy, flexibility, timeliness, readership and consistency (Zheng Haixia, 2017: 16-21) [13]. External publicity translation in high quality will help Chinese culture go abroad and help the world to break stereotypes and understand the real China.

As for culture, because of its rich connotation and interdisciplinary characteristic, there is no accurate and fixed definition of culture. In Chinese, the word "culture" is composed of two Chinese characters "Wén" and "Huà". The character "Wén" refers to "the interweaving of various colors" with the extended meaning of "various symbols, cultural relics, ancient books, etiquette systems, etc."; while the character "Huà" refers to "generation, creation", with the extended meaning of "transformation, education, cultivation". The combining use of "wén huà" first appeared in the Western Han Dynasty (around 202 B.C-8 A.D). In Shuoyuan, written by Liu Xiang, there is “圣人之治天下也, 先文德而 后武力。凡武之兴, 为不服也; 文化不改, 而后加诛”(cited Yu Yanying et al., 2016: 1) [3]. In modern Chinese, it means when a sage governs his people, he will first civilize them with culture and morality and then conquer them by force. The governor, who uses force to conquer his people, will not be convinced; if he governs his people with culture and virtue but nothing has changed, the punishment can be used. In 1871, Edward Burnett Tylor, the founder of British cultural anthropology, made a systematic description of the central concept in his book Primitive Culture: Culture, or civilization, taken in its wide enthnograghic sense, is that complex whole which includes knowledge, belief, art, morals, law, custom, and other capabilities and habits acquired by man as a member of society (Tylor, 1903: 1) [14]. Therefore, culture is unique to a certain region.

The cultural translation involved in the English version of the work report 2019 mainly focuses on the following points.

\subsection{Translation of Political Words with Chinese Characteristics}

A large number of political words in the work report is one of the major features of external publicity. These political words reflect a kind of times and national policy orientation, which are concise but rich in connotation. In the process of translation, understanding the pragmatic meaning of these words is not only the key to own the recognition by target readers, but also one of the important ways to accurately convey Chinese political ideas to the target readers. One of the scholars who discussed the translation of "zhōng guó mèng" (Chinese dream), one of the most typical culture-loaded words, and pointed out that context dependence must be emphasized when translating culture-loaded words (Liu Hongwei, 2017) [15]. In the work report, the translation of political words 
mainly includes the following ways:

Literal translation:

1) 三大攻坚战(sān dà gōng jiān zhàn) the three critical battles

2) “五位一体”总体布局(“wŭ wèi yì tù” zōng tĭ bù jú) the five-sphere integrated plan

3) “四个全面”战略布局 (“sì ge quán miàn” zhàn lüè bù jú) four-pronged comprehensive strategy

4) 大众创业, 万众创新 (dà zhòng chuàng yè, wàn zhòng chuàng xīn) Business startups and innovation

5）简政放权、放管结合(jiăn zhèng fàng quán, fàng guăn jié hé) streamline administration and delegate power, improve regulation

6) “证照分离”(“zhèng zhào fēn lí”) the reform separating permits from the business license Free translation:

7) “三去一降一补”(“sān qù yī jiàng yī bŭ”) consolidate the gains made in the five priority tasks

8) “破、立、降”(“pò, lì, jiàng”) to cut ineffective supply, foster new growth drivers, and reduce costs in the real economy

9) “双随机、一公开”(“shuāng suí jī, yī gōng kāi”) oversight conducted through the random selection of both inspectors and inspection targets and the prompt release of results

10) “两项补贴”(“liăng xiàng bŭ tiē") living allowances and nursing care subsidies

11) “四风”("sì fēng”) formalities performed for formalities' sake, bureaucratism, hedonism, and extravagance

12) “三公”经费(sān gōng jīng fèi) spending on official overseas visits, official vehicles, and official hospitality

According to the above selected examples, it can be seen that when translating the political words, free translation accounts for a large proportion of the whole text. Most of the words in literal translation are those have already mentioned before, or explained directly after the terms. Wang Kefei (2016: 90) [16] pointed out that when there is a complete vacancy in translation, transliteration (translate according to the pronunciation of the source language) and literal translation are preferred, and free translation is supplemented. It is not difficult for the English reader to understand this kind of vocabulary. The meaning of those complex proper nouns in original text are well explained by free translation. In this way, English readers' confused memory of too many proper nouns can be reduced, to a large extend.

In the work report 2019, free translation is commonly used in political words translation. Compared with literal translation, free translation can convey the 
exact meaning of the original proper nounsmore accurately. This kind of translation is more specific, less abstract, and has an ideal one-to-one correspondence. For example, "zhèng" and "zhào" in Chinese, both have the meaning of "accredited certificate", which is a general reference. In this context, it refers to business licence and licence of permit for operation. "shuāng suí jï" refers to the random selection of inspection targets, and the random selection of inspectors, "yī gōng kāi" means let the public know the inspection results. Native Chinese may also confused about those political proper nouns, let alone English readers. Under these circumstances, it is much more appropriate to adopt free translation.

\subsection{Translation of Four-Character Expression and Idioms}

1) 勇于担当, 恪尽职守, 竭尽全力(yŏng yú dān dāng, kè jìn zhí shŏu, jié jìn quán lì)

shoulder our responsibility, fully perform our duties, and do all we can

2) 贵在行动、成在坚持(guì zài xíng dòng, chéng zài jiān chí) forged ahead and overcame difficulties

3) 尽力而为、量力而行 (jìn lì ér wéi, liàng lì ér xíng) do everything within our capacity

4) 砥砺奋进, 攻坚克难(dĩ lì fèn jìn, gōng jiān kè nán)

(its success) hinges on action and commitment

The translation methods of four-character expressions and idioms in the work report 2019 are mainly divided into literal translation and free translation, too. By literal translation, such as the first sentence, all the three expressions are translated with the same grammar pattern with Chinese text. Literal translation is often used in four-character expressions.

In Chinese, each expression in example 2) and 3) are consistent in grammatical structure: the former two expressions are both "verb + complement", the latter are "adverb + verb". In Chinese, they are obviously in couplet form, and the parallel structure in English can also be adopted in order to reach grammar consistency. However, in English version, the structure of example 2) is "verb + adverb, verb + noun", which results in a lack of structural equivalence. Besides, "gui", which means "expensive or precious", is not translated. The two fourcharacter expressions in example 3) both have the similar meaning. In Chinese, synonyms are used to express the momentum and strong tone of language. While in English, repeated use of words with the same or similar meaning does not achieve the expected effect of the original text, but may have the opposite result of redundancy, which is to take care of the audience of the English version. "dĭ lì" and "fèn jìn", "gōng jiān" and "kè nán" also share a similar meaning respectively, thus, in English, the similar elements are omitted and the modifiers are weakened, but the behavior "action" and shown in the original text are highlighted. "Commitment" is an added element in English version. This also shows that due to different cultural backgrounds, we should pay attention to the 
cultural environment of the target reader when translating.

\subsection{Translation of Chinese Allusions}

In political speeches, it is a common phenomenon that speakers cite sentences or words from classics. The reasons for citation are as follows: to strengthen the tone of the language itself and the cultural connotation of the speech, and the most important is to spread the excellent traditional Chinese culture. As one of the non-literary text, citation is also another distinct feature of the work report. For example:

1) 思危方能居安(sī wēi fāng néng jū ān)

Only alertness to danger will ensure safety.

The language is clear, accurate and concise in a formal style text. The original sentence originates from Chinese idioms "jū ān sī wēi". Zuo Zhuan records that “书曰: ‘居安思危'思则有备, 有备无患”(Yang Bojun, 2018(a): 855) [17], which means in a safe and stable environment, we should always be alert to potential threats. The English version is much more concise than the previous translation. "sī wēi" is regarded as the precondition of "jū ān", which makes the hidden conditions of the idiom clear. There are also proverbs like "In time of peace prepare for the war." or "In fair weather prepare for the foul" in English. This example is one of the typical examples of foreignization. Also there is:

2) 为政以公, 行胜于言 (wéi zhèng y̆ gōng, xíng shèng yú yán)

Government works for the public; words can't compare with actions.

This sentence is adapted from Chinese idiom "wéi zhèng yı̆ dé" and "xíng shèng yú yán”. The Analects of Confucius records that “子曰: “为政以德, 譬如 北辰居其所而众星共之”'(Yang Bojun, 2018(b): 14) [18], which means if the ruler governs his people by virtue, he will be supported by his people just like Polaris surrounded by other stars. It shows how important virtue is. With the progress of the times, when the rule of virtue has made some progress, the leader needs to pay attention to the fundamental interests of the overwhelming majority of the people. Therefore, the expression "wéi zhèng yĭ gōng" derived. "Xíng shèng yú yán" is also the school spirit of Tsinghua University. In English, there is a proverb that "actions speak louder than words", which seems to be a much more acceptable translation, but this translation is not adopted. Foreignization is preferred.

Although there are few allusions in the work report, they are also cultural phenomena that can not be ignored when translating. Allusions should not be translated in a careless way. The translator must go deep into the historical and cultural background of allusions, historical origins for example, and understand their original meaning, derived meaning as well as figurative meaning. Then, try to translate the allusions as appropriate as possible. "bringing principle" is encouraged in allusion translation. "It is the responsibility of every translator to absorb the essence of the source culture and enhance the vitality of the national culture" (Tian Chuanmao et al., 2017: 91) [19]. In the English version of the 
work report, the translation of allusions is literal, which shows the beauty of Chinese traditional culture.

Besides, there are also number translation, but the translator did not adopt domestication. "Sān băi liǜ shí" literally means the number three hundred and sixty, but "sān băi liǜ shí háng", an old saying, is translated in to "a vast range of talent". In China, the pragmatic meaning of some numbers is not limited to their literal meaning. "Mŭ" belongs to Chinese traditional measurement system, $1 \mathrm{mu}$ equals to 15 hectares. In the report " 8000 wàn mŭ" is translated into " 5.33 million hectares", which takes target readers' thinking pattern into consideration.

From above examples, domestication can be easily found in the English version of the work report 2019, while foreignization is quite rare. The purpose of external publicity translation is to spread China's mainstream political ideas and the excellent traditional Chinese culture as much as possible. The final represented translation text is the result of the interaction between the translator, the author and the reader and the acceptability of such text depends on the level of the translator's interaction invisibility (Ren Dongsheng et al., 2018: 72) [20].

\section{Conclusions}

The translation of the external publicity text involves the translator's political position and his sense of the political trend of the country. The words with Chinese characteristics belong to culture loaded word. "China has its own unique historical tradition, realistic national conditions, lifestyle and way of thinking, which makes some Chinese words have special cultural connotations and become the common cultural presupposition of the Chinese people, that is, internalization becomes the self-evident cultural background information of the Chinese cultural community, which also brings great obstacles to cross-cultural communication" (Tian Chuanmao, 2017: 260) [19]. The translation violence of cultural centralism criticized by Venuti requires the translator to get rid of the status of invisibility and keep the differences of culture in a way of "decentralism", which places an important guidance on cultural translation. Pym (1996: 170) holds the opinion that domestication is also widely applied in other languages translation [21].

However, foreignization may bring some negative effects to the translation field of our country, and give those who are not good at translation a theoretical excuse to produce a large number of poor quality translation under the banner of foreignization (Ma Huijuan, 2006: 31) [22]. Venuti (2008: 264) [9] insists that "a translated text should be the site where linguistic and cultural differences are somehow signaled, where a reader gets some sense of a cultural other, and resistancy, translation strategy based on an aesthetic of discontinuity, can best signal those differences, that sense of otherness, by reminding the reader of the gains and losses in the translation process and the unbridgeable gaps between cultures". 
The translation violence of cultural centralism criticized by Venuti requires the translator to get rid of the status of invisibility and keep the differences of culture in a way of "decentralism", which enrich the language expression of the target language and places an important guidance on cultural translation. However, examples in this article are incomplete and there is no diachronic study. If all the culture-loaded words in the work report are collected into a small corpus in chronological order, the conclusion will be more accurate. In this special era, translators, as cultural bridges and envoys, can only take on the lofty responsibility of integrating Chinese and foreign characteristics of the times ... and telling a good story of China and convey a good voice of China (Huang Youyi, 2015: 7) [23].

\section{Acknowledgements}

This paper is supported by the project of "Courses for cultivating innovation and entrepreneurship (2019)" of East China University of Science and Technology.

\section{Conflicts of Interest}

The authors declare no conflicts of interest regarding the publication of this paper.

\section{References}

[1] 贾毓玲. 对中央文献翻译的几点思考[J]. 中国翻译, 2011, 32(1): 78-81.

[2] 黄友义. 坚持“外宣三贴近”原则, 处理好外宣翻译中的难点问题 [J]. 中国翻译, 2004(6): 29-30.

[3] 于艳英, 陈柯, 蔡晓青. 外宣翻译的汉语文化转向 [M]. 北京: 地质出版社, 2016: $1-30$.

[4] 陶全胜. 从翻译目的论看企业外宣资料汉英翻译原则 [J]. 合肥工业大学学报(社 会科学版), 2005(4): 124-129.

[5] 孙雪瑛, 冯庆华. 目的论视域中的企业外宣翻译 [J]. 外语学刊, 2014(4): 98-102.

[6] 徐敏, 胡艳红. 功能翻译理论视角下的企业外宣翻译 [J]. 华中科技大学学报(社 会科学版), 2008(3): 107-111.

[7] 徐敏慧, 董华. 从功能翻译理论看对外宣传材料汉译英[J]. 中国海洋大学学报 (社会科学版), 2007(3): 86-89.

[8] 胡芳毅. 操纵理论视角下的外宣翻译一一政治文本翻译的改写 [J]. 中国科技翻 译, 2014, 27(2): 40-42+39.

[9] Venuti, L. (2008) The Translator's Invisibility: A History of Translation. Routlege, London.

[10] Venuti, L. (1998) The Scandal of Translation: Towards an Ethics of Difference. Routlege, London. https://doi.org/10.4324/9780203269701

[11] Munday, J. (2016) Introducing Translation Studies: Theories and Applications. 4th Edition, Routledge, London and New York. https://doi.org/10.4324/9781315691862

[12] Lefevere, A. (ed. and tr.) (1977) Translating Literature: The German Tradition from Luther to Rosenzweig, Assen: Van Gorcum. 
[13] 郑海霞. 跨文化视域中的外宣翻译研究 [M]. 北京: 中国水利水电出版, 2017: 16-21.

[14] Tylor, E.B. (1903) Primitive Culture: Research into the Development of Mythology, Philosophy, Religion, Language, Art, and Custom. Vol. 1, 4th Edition, John Murray, London.

[15] 刘宏伟. 政治术语跨文化传播中的语境依赖性一一以 “中国梦”英译为例 [J]. 天津 外国语大学学报, 2017, 24(3): 1-6+80.

[16] 王克非, 王颖冲. 论中国特色文化词汇的翻译 [J]. 外语与外语教学, 2016(6): 87-93+149-150

[17] 杨伯峻. 春秋左传注(下) [M]. 北京: 中华书局, 2018: 855 .

[18] 杨伯峻. 论语译注[M]. 北京: 中华书局, 2018: 14 .

[19] 田传茂, 王峰. 翻译与文化[M]. 北京: 中国社会科学出版社, 2017: 3 .

[20] 任东升, 王芳. 译者交互隐形与译本呈现[J]. 外语研究, 2018, 35(6): 69-72.

[21] Pym, A. (1996) Venuti's Visibility. Target, 8, 165-177. https://doi.org/10.1075/target.8.1.12pym

[22] 马会娟. 对 Lawrence Venuti 异化翻译理论的再思考[J]. 天津外国语学院学报, 2006(1): 26-32.

[23] 黄友义. 中国站到了国际舞台中央, 我们如何翻译[J]. 中国翻译, 2015, 36(5): 5-7. 